\title{
A Study On Cost-Effectiveness Of Higher Education With Particular Reference To Barama College.
}

\author{
Jayanta Kumar Das \\ Assistant Professor,Department of Education.Bajali College, Pathsala. Assam. India
}

\begin{abstract}
Effectiveness of cost should be determined by the extent of successful completion of the stated objectives. Opening of more primary schools, appointment of more teachers and provision of free lunch scheme are aimed at eradication of illiteracy among children.The present study was carried out to study the enrolment pattern of students and recruitment pattern of teachers. To examine the different components of receipts and expenditure. To examine the effectiveness of the institution in terms of results of H.S. and B.A. examinations.The important findings of the present study are: The College came under deficit grant-in-aid system in 1978 after 7 years of establishment. The male female ratio of the teaching staff is $4: 1$. Government grant was the major source of funds. The college has introduced some specific procedures for income generation like Fishery, Agriculture, which can be considered a significant step for enhancing finances.
\end{abstract}

Key words: Cost- effectiveness, Enrolment, Recruitment, Grants.

\section{INTRODUCTION:}

Effectiveness of cost should be determined by the extent of successful completion of the stated objectives. Opening of more primary schools, appointment of more teachers, and provision of free lunch scheme are aimed at eradication of illiteracy among children.If this objective is not achieved the cost incurred can not be termed as effective, though it has benefited many people. Cost effectiveness analysis is result oriented and anticipates total achievement of objectives.

Mark Blaug had outlined the steps in cost - effectiveness analysis:

- Objectives of the scheme/project should be stated in operational (measurable) terms.

- Optimum input mix should be calculated to reduce cost.

- Each objective should be rearranged on the basis of weights given to them.

- Objectives should be achieved through economic utilization of resources.

- Evaluate achievement of each and every objective.

\section{METHODOLOGY AND PROCEDURE:}

Introduction:

To carry out any type of research investigation a sound methodology with effective procedure is vital to achieve the goal. A great variety of method and procedure have been developed to aid in the acquisition of data. In this paper, the method and procedure adopted by the investigator in the present study has been discussed under the

- The nature of the study following captions.

- Selection of sample

- Description of the tools

- Procedure of data collection

Nature of the study:

The topic of the present study reads as- "A study on cost-effectiveness of higher education with particular reference to Barama College". For present study the case study method has been followed.

Case Study:

The case study is an intensive investigation of a social unit. The social unit may be an individual, a family, a school, a group of delinquents, drop outs, or any teenage gang.In a case study, the researcher attempts to examine an individual or unit in depth. He gathers pertinent data about the present status, past experience, and environmental forces and contribute to the behaviour to the individual or social unit, and how these factors and their Interrelationships help the researcher to construct a comprehensive and integrated picture of the unit. 


\section{Selection of sample:}

The following points are kept in view the selection of Barama College is made.

- The college is situated in a backward areas under the Gauhati University. The area is Earmarked as reserved constituency as tribal population constitute $55 \%$ of the total population.

- It is non-government college.

- This college represented the various financial problems which are also represented by other non-government colleges.

- Selection of sample:

The group from which the sample has been drawn is known as the universe or population and the group actually selected for study is called sample. The sample should also represent the population truly.The present study represents Barama College, office staff, teaching staff, and the students. Barama college covers all the students from both rural and urban areas etc.

\section{Description of the tools:}

To carry an any type of investigation, data gathering must, specially for testing the hypothesis set up for its purpose. The instruments which are employed for gathering new facts for exploring new fields are called "Tools". Each tool is useful in collecting data so as to yield such information as could be most effectively used in the investigation. Best writes- 'some research investigations use but one of these devices. Others employ a number of them in combination.In the present study following kinds of tools are used for collection of data:

- Questionnaire

- Interview

Questionnaire:

According to good and Hatt, questionnaire refers to a device for securing answer to questions by using form which the respondent fills in himself.To receive desired factual information a questionnaire is also used. In a questionnaire, as is evident from the name, a list of selected questions is complied. It makes possible to economies time and expenditure to the placement of a number of responses in one place. The most important point regarding the use of questionnaire is that the questionnaire must first decide why the questions are being asked and also he must know exactly what is to be done with the responseQuestionnaire is that main tool employed for the present investigation and carefully constructed in the light of other questionnaires which are available. The questionnaire used in the present study is about students' enrolment, Teachers' recruitment, college receipts and expenditure pattern and about the H.S. \& B.A. examination results. In the process of preparation of this questionnaire the investigator approached the staff of the college.Before asking the office and teaching staff to their answers to the questions, the investigator explained the purpose of the questionnaire.

\section{Interview:}

Opinions from the principal, teaching staff, office staff and the students are taken on different aspects of the Barama College. The interview is in a sense an oral questionnaire. The questionnaire is a piece of printed paper somewhat impersonal and creates a slight mental barrier. Interview aims at a good report and the over throw of that barrier. The interview can be regarded as a set of questionnaire personally and verbally given. The interview is one of most important tools and is dependent for its Success on its personal ability of the interviewer more than any other method of data Collection. A good interviewer who is able to establish sympathetic content with subject cannot get responses which otherwise cannot be elicited.In the present study interview is employed to the principal, office staff, teaching staff and the students of the college, all the necessary responses of different interviews are immediately noted.

\section{Procedure of data collection:}

For the Collection of data, the copies of questionnaires were given to the office staff of the Barama College. At the same time, the investigator went personally to the principal of the college, the Vice-Principal of the College and also met the various office staff and the teaching staff. The principal, the vice-principal, the office staff and the teaching staff of the college were very co-operative. Though there was no time limit for the questionnaire the college office staff were requested to complete the same as early as they could. When the office staff have completed the questionnaire, the investigator collected them. While collecting the questionnaires from the office staff care was taken to check the unresponded parts of the questions. If any item was left out, the office staff were requested to complete the same.

\section{MAJOR FINDINGS AND SUGESTIONS :}

Major observation and conclusion which are drawn on the basis of the obtained findings of the study may be summarised as follows: 
- The college came under deficit grant-in-aid system in 1978 after 7years of establishment.

- Science section was introduced at the Higher Secondary level in1992. Introduction of Science section was very late. And it will need rapid development in future.

- The highest enrolment of student was the year 1992-93. In that year total enrolment of students was 1592. Out of this, 996 students from H.S. ( Arts) and the rest 596 students from Degree (Arts)

- The posts of the teaching staff were sanctioned in the deficit year, 1978.

- The number of male teacher is greater than the female teacher. The male female ratio of the teaching staff is 4:1. The percentages are $77.78 \%$ and $22.22 \%$ respectively.

The number of Science teacher is 4 and number of Arts teacher is 32. The number of female teacher is not adequate for the college. Because it is co-education system of education. So more female teachers should be appointed.

- Building grant was given to the college from the year 1981-82.

- College building was started in the year 1974-75.

- Government grant was the major source of funds.

- Salary was the major expenditure of the college.

- There was no deficit in expenditure in any year during the whole periods, Which reflected the effective administrative machinery.

- The year 1992 was the successful year in terms of Higher Secondary (Arts) result. The percentage of success was $43.94 \%$.

- The year 1993 was the successful year in terms of Degree (Arts) result. The percentage of success was $70.34 \%$.

- The college has introduced some specific procedures for income generation like Fishery, Agriculture, which can be considered a significant step for enhancing finances.

In conclusion, findings of the present investigation show that the cost-effectiveness study on higher education can be very effective, Specially may be very helpful to the planners of higher education.From the findings it was found that the government and the U.G.C. should give more grants to the non-government colleges.

\section{CONCLUSION}

From the above study the investigator has reached at a conclusion that the cost-effectiveness is a new concept for the state of Assam, it has great importance in the field of higher education of Assam,Specially at the college level. This cost-effectiveness study on Barama College will be a role model to other colleges of Assam. Barama College situated in backward tribal area of Nalbari District(now in Baksa District) is serving as a centre of higher learning to the poor students of the area. Every year many students come from various parts of the area to study in this institution. The economic conditions of the average students are poor. Still the college examination results have been good. The college should give importance in the development of science faculty. The findings of the study have been incorporated in the preceding paragraphs and these findings will go a long way in helping future researchers.

\section{REFERENCES}

[1] Blaug. M. Economics of EducationPenguin Books Ltd.Harmondsworth, MiddlesexEngland.

[2] Best. J.W. Research in Education,Prentice Hall of India.New Delhi-110001 Devi. S. Economics ofHigher EducationAnuBooks, shivaji RoadMeerut- India.

[3] Fourth survey of Research in Education, 1983-88 Vol. I. N.C.E.R.T.

[4] Harbison. F. Education, manpower.Myers. C.A. An Economic growthOxford \& IBH publishing co.New Delhi-1.Koul. L. Methodology of EducationalResearch.Vikash Publishing House Pvt. Ltd.New delhi110014.

[5] Mason. E.J. Understanding and conductingResearch/Application in education and Behavioural Sciences.Mc grow-Hill Book CompanyNew Delhi.Measurement of Cost Productivity and Efficiency of EducationN.C.E.R.T.

[6] Natarajan. S. Introduction to Economics of education.

[7] Sidhu K.S. Methodology of Research in Education.Sterling publishing pvt.LtdL-10.Green Park extention.New Delhi-110016

[8] Third survey of research in education N.C.E.R.T.13. Venkatasubramanian. K. Education and economic development in India. Frank Bros \& Co. ChandniChowk. Delhi-6. 